University of Wollongong

Research Online

Faculty of Engineering and Information

Faculty of Engineering and Information

Sciences - Papers: Part B

Sciences

2016

\title{
Axial-flexural interactions of GFRP-CFFT columns with and without reinforcing GFRP bars
}

Qasim S. Khan

University of Wollongong, qasim@uow.edu.au

M Neaz Sheikh

University of Wollongong, msheikh@uow.edu.au

Muhammad N. S Hadi

University of Wollongong, mhadi@uow.edu.au

Follow this and additional works at: https://ro.uow.edu.au/eispapers1

Part of the Engineering Commons, and the Science and Technology Studies Commons

Research Online is the open access institutional repository for the University of Wollongong. For further information contact the UOW Library: research-pubs@uow.edu.au 


\title{
Axial-flexural interactions of GFRP-CFFT columns with and without reinforcing GFRP bars
}

\begin{abstract}
This study presents the results of an experimental program and analytical modeling for axial-flexural interactions of concrete-filled glass fiber-reinforced polymer tube (GFRP-CFFT) columns with and without reinforcing glass fiber-reinforced polymer (GFRP) bars. The experimental program included four steel RC specimens, four GFRP-CFFT specimens, and four GFRP bar-reinforced GFRP-CFFT specimens with an outer diameter of $205-206 \mathrm{~mm}$ and a height of $800-812 \mathrm{~mm}$. The specimens were tested under concentric and 25- and 50-mm eccentric axial loads and four-point load. The experimental results showed that GFRP bar-reinforced GFRP-CFFT specimens sustained higher peak axial loads, axial and lateral deformations at peak axial load, and flexural loads than GFRP-CFFT specimens without reinforcing GFRP bars and steel $\mathrm{RC}$ specimens. Axial load and bending moment (P-M) interactions of GFRP-CFFT specimens with and without reinforcing GFRP bars and steel RC specimens were analytically modeled. A parametric study was conducted to evaluate the effects of actual confinement ratio and GFRP bar reinforcement ratio on P$M$ interactions of GFRP-CFFT specimens. The P-M interactions were found to be significantly affected by both actual confinement ratio and GFRP bar reinforcement ratio.
\end{abstract}

\section{Keywords}

gfrp-cfft, axial-flexural, without, columns, gfrp, bars, interactions, reinforcing

Disciplines

Engineering | Science and Technology Studies

\section{Publication Details}

Khan, Q. S., Sheikh, M. Neaz. \& Hadi, M. N. S. (2016). Axial-flexural interactions of GFRP-CFFT columns with and without reinforcing GFRP bars. Journal of Composites for Construction, Online First 1-12. 


\title{
Axial-Flexural Interactions of Concrete Filled Glass Fiber Reinforced
} Polymer Tube (GFRP-CFFT) Columns with and without reinforcing GFRP bars

\author{
Qasim S. Khan ${ }^{1}$, M. Neaz Sheikh ${ }^{2}$, Muhammad N.S. Hadi ${ }^{3 *}$ F.ASCE, \\ ${ }^{1}$ Ph.D. Candidate, School of Civil, Mining and Environmental Engineering, University of \\ Wollongong, Australia; formerly, Assistant Professor, Civil Engineering Department, \\ University of Engineering and Technology, Lahore, Pakistan \\ ${ }^{2}$ Senior Lecturer School of Civil, Mining and Environmental Engineering, University of \\ Wollongong, Australia \\ 3*Associate Professor, School of Civil, Mining and Environmental Engineering, University of \\ Wollongong, Australia, Corresponding Author \\ Email: $\underline{\text { mhadi@uow.edu.au }}$
}

\section{Abstract}

This study presents the results of an experimental program and analytical modelling for axialflexural interactions of Concrete Filled Glass Fiber Reinforced Polymer Tube (GFRP-CFFT) columns with and without reinforcing Glass FRP (GFRP) bars. The experimental program included four steel Reinforced Concrete (RC) specimens, four GFRP-CFFT specimens and four GFRP bar reinforced GFRP-CFFT specimens of 205 - 206 mm outer diameter and 800 $812 \mathrm{~mm}$ height. The specimens were tested under concentric, $25 \mathrm{~mm}$ and $50 \mathrm{~mm}$ eccentric axial loads and four-point load. The experimental results showed that GFRP bar reinforced GFRP-CFFT specimens sustained higher peak axial loads, axial and lateral deformations at peak axial load and flexural loads than GFRP-CFFT specimens without reinforcing GFRP bars and steel RC specimens. Axial load and bending moment $(P-M)$ interactions of GFRP-CFFT specimens with and without reinforcing GFRP bars and steel RC specimens were analytically modelled. A parametric study was conducted to evaluate the effects of actual confinement ratio and GFRP bar reinforcement ratio on $P-M$ interactions of GFRP- 
CFFT specimens. The $P-M$ interactions were found to be significantly affected by both actual confinement ratio and GFRP bar reinforcement ratio.

32 Keywords: GFRP-CFFT; GFRP bar; Axial loads; Four-point load; Stress-strain model; $P-M$ interaction

\section{Introduction}

Steel bar Reinforced Concrete (RC) columns are used in bridges and buildings to transfer loads from superstructure to substructure. The load carrying capacity of steel RC column reduces over the design life of the structure due to corrosion of steel bars. The large repair and maintenance costs and strength deterioration of steel RC columns over the design life are among the main concerns associated with steel RC columns. The National Association of Corrosion Engineers International reported that the United States annually spend about \$2 billion for repairs and replacement of bridge piers and about $\$ 1$ billion for marine piling systems (Mohamed et al. 2014). One of the solutions to reduce repair and maintenance costs is to use FRP reinforcement as a substitute of steel reinforcement for the construction of new concrete structures for increased service life and economy (Hadi et al. 2016a).

In the last two decades, Concrete Filled Fiber Reinforced Polymer Tube (CFFT) emerged as a new and attractive form of Fiber Reinforced Polymer (FRP) reinforcement for the construction of new structural members (e.g. bridge piers, building columns and overhead sign structures). In CFFT columns, FRP tube serves as lightweight formwork, barrier to corrosion accelerating agents, and longitudinal and transverse reinforcement (Mirmiran et al. 1998a; Lillistone and Jolly 2000). The FRP tube restrains the lateral dilation of confined concrete and thereby increases confined concrete strength and ultimate confined concrete strain of CFFT columns. Moreover, FRP tube was reported to be more efficient in increasing the confined concrete strength under axial and flexural loads than steel tubes (Fam and 
Rizkalla 2001). The earlier studies demonstrated that CFFT columns sustained large inelastic deformations which makes FRP tube an attractive alternative of steel reinforcement for the construction of new concrete columns with high strength and ductility (Yamakawa et al. 2003; Gu et al. 2010). Several studies reported increased strength and ductility of CFFT columns under different load conditions due to higher effectiveness of FRP tube confinement than that of steel helix (Mirmiran et al. 1998b; Xiao et al. 1999; Fam and Rizkalla 2001, 2002; Hong and Kim 2004; Fam et al. 2005; Ozbakkaloglu and Saatcioglu 2006; Zhu et al. 2006; Mohamed and Masmoudi 2008a; Mohamed and Masmoudi 2010; Ozbakkaloglu 2013; Vincent and Ozbakkaloglu 2013; Idris and Ozbakkaloglu 2014, 2015; Khan et al. 2016; Wang et al. 2016).

In recent years, the use of FRP bar was investigated as a practicable alternative of steel bar in RC members for increased service life and reduced repair costs in harsh corrosive environments (Tobbi et al. 2012). FRP bars have excellent corrosion resistance and greater tensile strength to weight ratio than steel bar (Zadeh and Nanni 2013). The available studies on FRP bar reinforced concrete columns tested under concentric axial loads reported that FRP bar reinforced concrete columns resisted smaller axial loads than steel bar reinforced concrete column. De Luca et al. (2010) and Tobbi et al. (2012) reported that GFRP bar reinforced square concrete columns resisted 2.9 - 12\% smaller axial loads than steel bar reinforced square concrete columns. Alsayed et al. (2012) reported that Glass FRP (GFRP) bar reinforced rectangular concrete columns resisted $13 \%$ smaller axial loads than steel bar reinforced rectangular concrete columns. Afifi et al. (2014a) reported that GFRP bar reinforced circular concrete columns resisted 7\% smaller axial loads than steel bar reinforced circular concrete columns. Afifi et al. (2014b) reported that Carbon FRP (CFRP) bar reinforced circular concrete columns resisted 5\% smaller axial loads than steel bar reinforced circular concrete columns. Hadi et al. (2016b) reported that GFRP bar reinforced circular 
concrete columns resisted $12 \%$ smaller axial loads than steel bar reinforced circular concrete columns. However, FRP bar reinforced concrete columns exhibited significantly reduced corrosion than steel RC columns. Pantelides et al. (2013) reported that in hybrid (steel bars and GFRP helix) reinforced concrete columns minor level of corrosion was observed with no visible detrimental effect on the steel bars and in GFRP bar reinforced concrete columns almost no corrosion was observed.

A number of research studies investigated the application of FRP bars as longitudinal reinforcement in FRP bar reinforced concrete columns tested under axial load. However, ACI 440.1R (2006) does not recommend the use of FRP bars as longitudinal reinforcement in FRP bar reinforced concrete columns under axial load as FRP bars have lower ultimate strength in compression than in tension. The CSA S806 (2012) permits the use of FRP bars as longitudinal reinforcement in FRP bar reinforced concrete columns under axial load but ignores the contribution of FRP bars in ultimate axial load capacity. The ACI 440.1R-15 (ACI 2015) does not include any recommendation for the use of FRP bars as longitudinal reinforcement in FRP bar reinforced concrete columns.

In recent years, a small number of research studies investigated axial load and ductility of steel bar reinforced Concrete Filled Glass Fiber Reinforced Polymer Tube (GFRP-CFFT) columns under concentric and eccentric axial loads. Mohamed and Masmoudi (2008b) reported that steel bar reinforced GFRP-CFFT columns sustained larger axial loads and ductility than unreinforced GFRP-CFFT columns due to the dowel action of steel bars. Mohamed and Masmoudi (2008a) reported that peak axial loads of steel bar reinforced GFRP-CFFT columns were reduced by $48.3 \%, 61.1 \%, 70.8 \%$ and $77.0 \%$ under applied axial load eccentricity of $15,30,45$ and $60 \mathrm{~mm}$, respectively, compared to the peak axial loads of steel bar reinforced GFRP-CFFT columns under concentric axial load. 
Most of the available research studies investigated the behavior of FRP bar reinforced concrete columns under concentric axial load. Although, columns in buildings are often subjected to combined axial load and bending moment due to construction errors, lateral loads and applied end moments (Hadi et al. 2013). To the knowledge of the authors, Fam et al. (2003) investigated the experimental and analytical axial load and bending moment interactions of high strength concrete filled GFRP tubes and Mohamed and Masmoudi (2008a) investigated the experimental axial load and bending moment interactions of steel bar reinforced normal strength concrete filled GFRP tubes. None of the studies investigated the experimental and analytical axial load and bending moment interactions of normal strength concrete filled GFRP tubes with and without reinforcing GFRP bars. This study investigates experimentally and analytically the axial load and bending moment interactions of Concrete Filled Glass Fiber Reinforced Polymer Tube (GFRP-CFFT) and GFRP bar reinforced GFRPCFFT specimens.

\section{Experimental Program}

The details of the experimental program with adequate illustrations of the test set up and test specimens were presented in Hadi et al. (2016a). For clarity, the experimental program is briefly reviewed herein. The experimental program comprised four steel bar Reinforced Concrete (RC) specimens, four Concrete Filled Glass Fiber Reinforced Polymer Tube (GFRP-CFFT) specimens and four GFRP bar reinforced GFRP-CFFT specimens. All specimens were tested at the High Bay Laboratories, School of Civil, Mining and Environmental Engineering, University of Wollongong, Australia. The specimens were divided into three groups with four specimens in each group. The first group, REF consisted of steel RC specimens. The second group, GT consisted of GFRP-CFFT specimens. The third group, GTGR consisted of GFRP bar reinforced GFRP-CFFT specimens. From each group, the first specimen was tested under concentric axial load. The second specimen was tested 
under $25 \mathrm{~mm}$ eccentric axial load. The third specimen was tested under $50 \mathrm{~mm}$ eccentric axial load. The fourth specimen was tested under four-point load. The specimens were labelled in two parts. The first part represents the type of specimen (REF, GT and GTGR). The second part represents the load condition ( 0 for concentric axial load, 25 and 50 for $25 \mathrm{~mm}$ and 50 mm eccentric axial loads, respectively and B for four-point load). The test matrix is presented in Table 1.

The REF group was reinforced longitudinally with six N12 (12 mm diameter deformed) steel bars and helically with R10 (10 mm diameter plain bar) steel helix of $155 \mathrm{~mm}$ diameter center to center with a pitch of $60 \mathrm{~mm}$. In the REF group, a concrete clear cover of $15 \mathrm{~mm}$ at the top and bottom ends and a concrete clear cover of $20 \mathrm{~mm}$ at the side of the specimen were provided. The basis for the design of GT and GTGR groups was to devise alternatives of REF groups for regions where corrosion of steel reinforcement is a major concern. For GT and GTGR groups, GFRP tubes of $1.5 \mathrm{~mm}$ nominal thickness with inner layers of fibers oriented at $90^{\circ}$ to the longitudinal direction and outer layers of fibers oriented at $\pm 60^{\circ}$ to the longitudinal direction were selected (CST Composites 2014). In GFRP tubes, 38\% of the fibers were oriented along the circumferential direction and $62 \%$ of the fibers were oriented along the skew direction. The GFRP tubes consisted of $60 \%$ fibers and $40 \%$ resin by volume. The modulus of elasticity and ultimate tensile strength of GFRP tubes in the circumferential direction were $18 \mathrm{GPa}$ and $810 \mathrm{MPa}$, respectively. The modulus of elasticity and ultimate tensile strength of GFRP tubes in the longitudinal direction were $5.4 \mathrm{GPa}$ and $92.2 \mathrm{MPa}$, respectively (CST Composites). In GTGR group, six sand coated GFRP bars (15.9 mm nominal diameter) with all fibers oriented along the longitudinal direction (Pultruded bars) were glued to the inner side of GFRP tube $\left(60^{\circ}\right.$ apart $)$ along the circumference. The GTGR specimens were reinforced with $15.9 \mathrm{~mm}$ diameter GFRP bars and the REF specimens were reinforced with $12 \mathrm{~mm}$ diameter steel bars to have similar nominal axial load capacity. It is 
noted that elastic modulus of GFRP bars was lower than steel bars. Thus, for the same diameter, the axial stiffness of GFRP bars was lower than that of steel bars. In GTGR group, a concrete clear cover of $15 \mathrm{~mm}$ at top and bottom ends was provided.

All groups were cast with ready mix concrete obtained from a local manufacturer. All groups were cured by covering them with wet hessian rugs and plastic sheets. The REF group was removed from the formworks after 7 days. All groups were cured for 28 days. The 28 days average compressive strength of concrete cylinders tested based on AS 1012.9-1999 (AS 1999) was $37 \mathrm{MPa}$. The measured cross-sectional area of GFRP bar was $292 \mathrm{~mm}^{2}(19.3 \mathrm{~mm}$ diameter) based on immersion testing according to ISO 10461-1 (ISO 2015). The manufacturer provided nominal cross-sectional area of GFRP bar was $198 \mathrm{~mm}^{2}(15.9 \mathrm{~mm}$ diameter) (V-Rod 2012). The difference in measured and nominal cross-sectional areas of GFRP bar was due to the sand coat to enhance bonding with surrounding concrete. The nominal cross-sectional area of GFRP bar was used to calculate ultimate strength and modulus of elasticity of GFRP bar in tension and compression in this study. The average tensile strength of GFRP bar was $1395 \mathrm{MPa}$ and tensile modulus of elasticity of GFRP bar was $56 \mathrm{GPa}$ measured according to ASTM D7205/D7205M-2011 (ASTM 2011). The average compressive strength of GFRP bar was $846 \mathrm{MPa}$ and the average compressive modulus of elasticity of GFRP bar was $42 \mathrm{GPa}$ measured according to ASTM D695-2010 (ASTM 2010). The nominal average tensile strengths of R10 and N12 bars were $400 \mathrm{MPa}$ and $600 \mathrm{MPa}$, respectively, tested according to AS 1391-2007 (AS 2007).

\section{Instrumentation and Test Procedures}

174 The test groups were instrumented internally and externally to measure strains and 175 deformations in the reinforcement. In REF group, two strain gauges were attached on steel helix at mid-height of the specimens $\left(180^{\circ}\right.$ apart) to measure the circumferential strains in 
steel helix and two strain gauges were attached on two steel bars at mid-height of the specimens $\left(180^{\circ}\right.$ apart $)$ to measure the axial strains in steel bars. For GT and GTGR groups, a pair of strain gauges was attached in the circumferential direction at mid-height of the specimens $\left(180^{\circ}\right.$ apart) to measure the circumferential strains in GFRP tube. In addition, GTGR group was instrumented with two pairs of strain gauges fixed on two GFRP bars at mid-height of the specimens $\left(180^{\circ}\right.$ apart $)$ to measure the axial strains in GFRP bars. A laser triangulation was fixed at mid-height of the specimens tested under eccentric axial loads to measure the lateral deformations. Also, a laser triangulation was fixed at midspan of the specimens tested under four-point load to measure the midspan deflections. All groups were instrumented with two Linear Variable Displacement Transducers (LVDTs) fixed diagonally in the test machine $\left(180^{\circ}\right.$ apart) to measure the axial deformations. All groups were tested in the $5000 \mathrm{kN}$ Denison Universal Testing Machine (UTM). The specimens in all groups were preloaded to $100 \mathrm{kN}$ and unloaded to $20 \mathrm{kN}$ under a force controlled load application at a rate of $50 \mathrm{kN} / \mathrm{min}$. Initial loading-unloading was carried out so that the specimen placed in the UTM is aligned properly to the loading plates. Afterwards, testing was resumed under a displacement controlled load application at a rate of $0.3-0.5 \mathrm{~mm} / \mathrm{min}$ until the failure of the specimen.

\section{Test Results and Discussion}

Experimental results of specimens in all groups tested under different applied axial load eccentricity are presented in Table 2. The experimental results showed that increase in applied axial load eccentricity resulted in larger reduction in peak axial loads and corresponding axial deformations in GT and GTGR groups than in REF group, as GFRP reinforcement has smaller modulus of elasticity than steel reinforcement. The increase in applied axial load eccentricity resulted in larger increase in lateral deformations at peak axial load in GT and GTGR groups than in REF group. The circumferential strains in GFRP tube 
at mid-height of specimens in GT and GTGR groups at peak axial loads were larger than the circumferential strains in steel helix at mid-height of REF group at peak axial loads under different applied axial load eccentricity. The larger measured circumferential strains in GT and GTGR groups were because GFRP tubes provided continuous confinement to the concrete. Also, two-thirds of the fibers in GFRP tube were oriented along the circumferential direction which was effective in restraining the lateral dilation of the confined concrete. The large difference between the mid-height circumferential strain at peak axial load of Specimens GT-0 and GTGR-0 was attributed to the different failure location of the specimens. Specimen GT-0 failed at the mid-height of specimen from rupturing of fibers and crushing of concrete. Specimen GTGR-0 failed in top one-third height of the specimen from rupturing of fibers, and crushing of concrete and rupturing of the top end of GFRP bars. Fanggi and Ozbakkaloglu (2015) also reported differences in the circumferential stresses and strains due to the different failure locations of CFFT specimens. The differences between the mid-height circumferential strains at peak axial load of Specimens GT-25 and GTGR-25, and Specimens GT-50 and GTGR-50 were small as the test specimens failed at the mid-height of the specimens from rupturing of fibers and crushing of concrete.

The GTGR group carried about 63\% larger peak axial loads than GT group tested under different applied axial load eccentricity. This was attributed to the addition of GFRP bars in GTGR group which were effective in carrying axial loads. The measured axial strain in GFRP bars at peak axial load in GTGR group was about $72 \%$ of the measured axial strain in steel bars at peak axial load in REF group under different applied axial load eccentricity. The smaller axial strains in GFRP bars than steel bars are because of smaller modulus of elasticity of GFRP bar than steel bar. The experimental results showed that GFRP bars were effective in resisting axial loads and their contribution in ultimate axial load capacity should be properly accounted. 
227 Experimental results of specimens in all groups tested under four-point load are presented in

228 Table 3. Specimen GT-B resisted 66.6\% smaller peak flexural load than Specimen REF-B.

This was because only one-third of the fibers in GFRP tube were oriented along the longitudinal direction which was effective in resisting flexural loads. Specimen GTGR-B resisted 29.3\% larger peak flexural load than Specimen REF-B. This was because of the addition of GFRP bars in Specimen GTGR-B. Moreover, the measured strains in GFRP bars in Specimen GTGR-B were about $40 \%$ of the measured strains in steel bars in Specimen REF-B which showed that GFRP bars were effective in resisting flexural load. Specimens GT-B and GTGR-B exhibited large midspan deflections at peak flexural load and failed at midspan due to rupture of FRP tube. Similar observations were also reported in Idris and Ozbakkaloglu $(2014,2015)$ for FRP concrete steel double skin tubular specimens.

During the test no slippage at the interface of GFRP tube and concrete under four-point load (Specimens GT-B and GTGR-B) was observed. The bond between concrete and GFRP tube at the ends of Specimens GT-B and GTGR-B was intact without any significant sign of slippage. The measured tensile strain in the GFRP tube at midspan of Specimen GT-B and Specimen GTGR-B were 4.3 and 3.2 times larger, respectively, than the tensile strain in the steel helix at midspan of Specimen REF-B.

\section{Experimental Axial Load Bending Moment Interactions}

Experimental axial load bending moment $(P-M)$ interactions were constructed using peak axial loads and bending moments at the peak axial loads of REF, GT and GTGR groups tested under concentric axial load, $25 \mathrm{~mm}$ and $50 \mathrm{~mm}$ eccentric axial loads and four-point load (Fig. 1). In REF group, the peak axial load represents the maximum axial load carried by the gross cross-section (concrete cover and core) of the specimen before the spalling of concrete cover. In GT and GTGR groups, the peak axial load represents the maximum axial 
load carried by GFRP-CFFT before rupturing of GFRP tube. The bending moment $(M)$ of REF, GT and GTGR groups were calculated by taking into account the primary moment $\left(M_{1}\right)$ due to applied axial load eccentricity $(e)$ and the secondary moment $\left(M_{2}\right)$ due to lateral deformations $(\delta)$ at the peak axial load. Bending moment $(M)$ of specimens tested under applied axial load eccentricity was calculated using Equation (1) and bending moment of specimens tested under four-point load was calculated using Equation (2).

$$
\begin{gathered}
M=P(e+\delta) \\
M=\frac{P l}{6}
\end{gathered}
$$

where $e$ is the applied axial load eccentricity and $l$ is the span length of flexural test arrangement.

The experimental $P-M$ interactions of GT and REF groups were presented in Fig. 1. Specimen GT-0 carried 23.2\% larger axial load than Specimen REF-0. Specimen GT-25 carried 3.2\% smaller axial load than Specimen REF-25 and Specimen GT-50 carried 12\% smaller axial load than Specimen REF-50. Specimen GT-25 exhibited 5.6\% larger bending moment than Specimen REF-25. Specimen GT-50 exhibited 13.3\% smaller bending moment than Specimen REF-50. Specimen GT-B exhibited 48.9\% smaller bending moment than Specimen REF-B. The larger reduction in the peak axial loads and bending moments at peak axial loads in GT group than REF group was attributed to lower modulus of elasticity of GFRP tube than steel. The experimental results showed that GT group can only serve as an alternative of REF group under concentric axial load where corrosion of steel is a concern.

The Fig.1 shows the larger axial loads and bending moments of GTGR group than REF group. Specimen GTGR-0 carried 83.9\% larger axial load than Specimen REF-0. Specimen GTGR-25 carried 67.5\% larger axial load than Specimen REF-25 and Specimen GTGR-50 
carried 53.2\% larger axial load than Specimen REF-50. Specimen GTGR-25 exhibited 127.5\% larger bending moment than Specimen REF-25 and Specimen GTGR-50 exhibited 100.9\% larger bending moment than Specimen REF-50. Specimen GTGR-B exhibited $94.8 \%$ larger bending moment than Specimen REF-B. The larger peak axial loads and bending moments of GTGR group than REF group was because of the greater confinement effectiveness of GFRP tube in confining the concrete than the steel helix which resulted in larger peak axial loads and corresponding lateral deformations and bending moments. Also, the diameter of GFRP bar was larger than the steel bar and GFRP bars were effective in carrying axial loads. The experimental results showed that GTGR group can serve as an alternative of REF group under concentric and eccentric axial loads and four-point load where corrosion of steel is a concern.

The Fig. 1 shows the smaller axial loads and bending moments of GT group than GTGR group. The Specimen GT-0 carried 33\% smaller axial load than Specimen GTGR-0. Specimen GT-25 carried 42.2\% smaller axial load than Specimen GTGR-25 and Specimen GT-50 carried $42.5 \%$ smaller axial load than Specimen GTGR-50. Specimen GT-25 exhibited 53.6\% smaller bending moment than Specimen GTGR-25 and Specimen GT-50 exhibited 56.9\% smaller bending moment than Specimen GTGR-50. Specimen GT-B exhibited $73.8 \%$ smaller bending moment than Specimen GTGR-B. The larger peak axial loads and bending moments in GTGR group than REF group is attributed to the addition of GFRP bars in GTGR group.

\section{Analytical Modeling}

\section{Confinement Mechanism of FRP Confined Concrete}

294 In circular FRP confined concrete columns, the lateral nominal confinement pressure $\left(f_{l}\right)$ provided by FRP confinement is assumed to be uniformly distributed around the 
circumference of the confined concrete column (Fig. 2). The confinement mechanism of FRP

297

298

299

300

301

302

303

304

305

306

307

308

309

310

311

312

confined concrete is based on strain compatibility between FRP confinement and confined concrete, and equilibrium of forces acting on FRP confined concrete. Increase in applied axial load results in increase in axial strain and corresponding increase in lateral strain in concrete (expansion of concrete) due to Poisson's effect. The FRP confinement is of passive type and is activated due to expansion of concrete under increasing applied axial load. The nominal confinement pressure $\left(f_{l}\right)$ exerted by FRP confinement along the circumferential direction increases with expansion of concrete until FRP confinement is exhausted. Based on the assumption of strain compatibility, the circumferential strain in FRP confinement is equal to the lateral strain in confined concrete (De Lorenzis and Tepfers 2003). The $f_{l}$ exerted by FRP confinement along circumferential direction is obtained based on equilibrium of forces acting on FRP confined concrete (Equation 3):

$$
f_{l}=\frac{2 E_{F R P} t_{F R P} \varepsilon_{f u}}{D}
$$

where $E_{F R P}$ is modulus of elasticity of FRP confinement in the circumferential direction, $t_{F R P}$ is the thickness of FRP confinement, $\varepsilon_{f u}$ is the ultimate tensile strain of fibers and $D$ is the diameter of FRP confined concrete. Replacing $\varepsilon_{f u}$ with the experimentally obtained circumferential rupture strain of fibers $\left(\varepsilon_{\text {rup }}\right)$ in Eq. 3 yields actual confinement pressure $\left(f_{l, a}\right)$ exerted by the FRP confinement as given in Eq. 4.

$$
f_{l, a}=\frac{2 E_{F R P} t_{F R P} \varepsilon_{r u p}}{D}
$$

313 The $f_{l, a}$ exerted by the FRP confinement is lower than the $f_{l}$ exerted by the FRP confinement due to the fact that $\varepsilon_{\text {rup }}$ is lower than the $\varepsilon_{f}$ due to manufacturing imperfections, construction errors and complex material behavior of FRP and confined 
concrete (Khan et al. 2016). The available stress-strain models for FRP confined concrete

317 which defined the stress-strain and ultimate confined concrete conditions (confined concrete strength and ultimate confined concrete strain) of FRP confined concrete in terms of $f_{l, a}$ are more accurate than the stress-strain models which defined the stress-strain and ultimate confined concrete conditions in terms of $f_{l}$ (Ozbakkaloglu et al. 2012).

\section{Modeling of Concrete Filled GFRP Tube}

Stress-strain models for FRP confined concrete in circular sections are broadly classified into design oriented models and analysis oriented models (Ozbakkaloglu et al. 2012). The design oriented models are simple closed form regression equations and are considered suitable for simple analytical modelling of FRP confined concrete. The design oriented models in Samaan et al. (1998) and Lam and Teng (2003) were considered suitable for the modelling of confined concrete in concrete Filled GFRP tubes in GT and GTGR groups. This is because Samaan et al. (1998) and Lam and Teng (2003) models take into account the effect of FRP confinement on the initial portion of the stress-strain curve and account for the strain hardening and strain softening behavior of FRP confined concrete. Also, the parameters in Samaan et al. (1998) and Lam and Teng (2003) models were calibrated with large experimental test databases. The ACI 440.2R-08 (ACI 2008) adopted Lam and Teng (2003) model with minor modifications for FRP confined concrete under axial force or combined axial and bending forces.

Samaan et al. (1998) stress-strain model for FRP confined concrete expresses axial stress of FRP confined concrete $\left(f_{c}\right)$ at a given axial strain $\left(\varepsilon_{c}\right)$, as given in Equation (5).

$$
f_{c}=\frac{\left(E_{c}-E_{2}\right) \varepsilon_{c}}{\left[1+\left(\frac{\left(E_{c}-E_{2}\right) \varepsilon_{c}}{f_{o}}\right)^{n}\right]^{1 / n}}+E_{2} \varepsilon_{c}
$$


337 where $E_{c}$ is the slope of the first ascending axial stress-strain curve and is equivalent to the

338 elastic modulus of concrete, $E_{2}$ is the slope of the second ascending axial stress-strain curve,

$339 f_{o}$ is the axial stress at the intercept of the second slope with the axial stress axis and $n$ is a

340 curve shape parameter which mainly controls the curvature of the transition point. The

341 parameters of Samaan et al. (1998) stress-strain model were calibrated with experimental

342 results of 30 GFRP-CFFT cylinders, as given in Equations (6 - 8):

343 where

$$
\begin{gathered}
E_{2}=245.61 f_{c o}^{0.2}+1.3456 \frac{E_{F R P} t_{F R P}}{D} \\
f_{o}=0.872 f_{c o}+0.371 f_{l, a}+6.258 \\
n=1.5
\end{gathered}
$$

344 Also, Samaan et al. (1998) proposed expressions to calculate FRP confined concrete strength 345 $\left(f_{c c}^{\prime}\right)$ (Equation 9) as a function of actual confinement pressure at ultimate $\left(f_{l, a}\right)$ (Equation 4) and unconfined concrete strength $\left(f_{c o}\right)$ and ultimate FRP confined concrete strain $\left(\varepsilon_{c u}\right)$ 347 (Equation 10) as a function of ${f^{\prime}}_{c c}, f_{o}$ and $E_{2}$.

$$
\begin{gathered}
f^{\prime}{ }_{c c}=f_{c o}+6 f_{l, a}^{0.7} \\
\varepsilon_{c u}=\frac{f_{c c}^{\prime}-f_{o}}{E_{2}}
\end{gathered}
$$

348 The model of Lam and Teng (2003) represents the stress-strain behavior of FRP confined 349 concrete with two curves i.e., parabolic first curve followed by linear-elastic second curve.

350 The parabolic curve meets the linear-elastic curve at a transition strain $\left(\varepsilon_{t}\right)$, as given in 351 Equations $(11-12)$. 


$$
\begin{gathered}
f_{c}=E_{c} \varepsilon_{c}-\frac{\left(E_{c}-E_{2}\right)^{2}}{4 f_{o}} \varepsilon_{c}{ }^{2}, 0 \leq \varepsilon_{c} \leq \varepsilon_{t} \\
f_{c}=f_{o}+E_{2} \varepsilon_{c}, \varepsilon_{t} \leq \varepsilon_{c} \leq \varepsilon_{c u}
\end{gathered}
$$

352 The parameters of Lam and Teng (2003) stress-strain model were calibrated with

353 experimental results of 76 FRP confined concrete cylinders, as given in Equations (13 - 15).

$$
\begin{gathered}
\varepsilon_{t}=\frac{2 f_{o}}{E_{c}-E_{2}} \\
f_{o}=f_{c o} \\
E_{2}=\frac{f_{c c}^{\prime}-f_{o}}{\varepsilon_{c u}}
\end{gathered}
$$

354 Also, Lam and Teng (2003) proposed expressions to calculate the FRP confined concrete 355 strength $\left(f_{c c}^{\prime}\right)$ (Equation 16) as a function of $f_{l, a}$ (Equation 4) and $f_{c o}$ and ultimate FRP 356 confined concrete strain $\left(\varepsilon_{c u}\right)$ (Equation 17) as a function of $f_{l, a}, f_{c o}, \varepsilon_{\text {rup }}$ and $\varepsilon_{c o}$.

$$
\begin{gathered}
f^{\prime}{ }_{c c}=f_{c o}+3.3 f_{l, a} \\
\varepsilon_{c u}=\left[1.75+12\left(\frac{f_{l, a}}{f_{c o}}\right)\left(\frac{\varepsilon_{r u p}}{\varepsilon_{c o}}\right)^{0.45}\right] \varepsilon_{c o}
\end{gathered}
$$

\section{Modeling of FRP Bar}

358 The axial stress-strain behavior of FRP bar is linear elastic till rupture (Kobayashi and

359 Fujisaki 1995; Deitz et al. 2003; ACI:440.1R 2006). The axial stress in GFRP bar $\left(f_{G i}\right)$ at a 360 given axial strain $\left(\varepsilon_{G i}\right)$ was calculated as a function of modulus of elasticity of GFRP bar in 361 compression $\left(E_{G i}\right)$, as given in Equation (18):

$$
f_{G i}=E_{G i} \varepsilon_{G i}
$$


The ACI 318M-2011 (ACI 2011) design guidelines for structural concrete ignores the contribution of steel helix confinement in the ultimate axial load capacity of steel RC column. In REF group, the confinement effect of steel helix at peak axial load was also ignored. This is because the circumferential strains in steel helix at peak axial load are $15 \%$ of the yield strain of steel bar (Mohamed et al. 2014). In REF group, the whole cross-section was analytically modeled as unconfined concrete cross-section with continuous axial stress-axial strain curve of concrete proposed by Popovics (1973), as given in Equations (19 - 20):

$$
\frac{f_{c}}{f_{c o}}=\frac{\varepsilon_{c}}{\varepsilon_{c o}} \frac{n^{\prime}}{n-1+\left(\frac{\varepsilon_{c}}{\varepsilon_{c o}}\right) n^{\prime}}
$$

370 where

$$
n^{\prime}=\frac{E_{c}}{E_{c}-\frac{f_{c o}}{\varepsilon_{c o}}}
$$

where $f_{c o}$ is unconfined concrete strength, $\varepsilon_{c o}$ is unconfined concrete strain corresponding to Tasdemir et al. (1998), as given in Equation (21).

$$
\varepsilon_{c o}=\frac{-0.067 f_{c o}{ }^{2}+29.9 f_{c o}+1053}{10^{6}}
$$

374 The modulus of elasticity of concrete $\left(E_{c}\right)$ was calculated as a function of $f_{c o}$ as given in ACI 318M-2011 (ACI 2011) (Equation 22):

$$
E_{c}=4730 \sqrt{f_{c o}}
$$


The axial stress-axial strain behavior of steel bar was analytically modeled as elastic-perfectly plastic. The axial stress in steel bar $\left(f_{s}\right)$ at a given axial strain $\left(\varepsilon_{s}\right)$ was calculated as a function of modulus of elasticity of steel bar $\left(E_{s}\right)$, as given in Equation (23):

$$
f_{s}=E_{s} f_{s} \leq f_{y}
$$

where $f_{y}$ is yield strength of steel bar.

\section{Analytical Axial Load Bending Moment Interactions}

Analytical axial load bending moment $(P-M)$ interactions of GT and GTGR groups were constructed using Samaan et al. (1998) and Lam and Teng (2003) stress-strain models for FRP confined concrete. Analytical $P-M$ interactions of Specimens REF were constructed using axial stress-axial strain curve of concrete proposed by Popovics (1973). The layer-bylayer numerical integration method was used to analyze circular specimen cross-sections.

The axial load capacity of GT and GTGR groups under concentric axial load was calculated using Equation (24), whereas the axial load capacity of REF group under concentric axial load was calculated using Equation (25).

$$
\begin{gathered}
P_{n}=0.85 f^{\prime}{ }_{c c}\left(A_{g}-A_{G F R P}\right)+\alpha f_{f u} A_{G F R P} \\
P_{n}=0.85 f_{c o}\left(A_{g}-A_{s}\right)+f_{y} A_{s}
\end{gathered}
$$

where $A_{g}$ is the gross sectional area of concrete, $A_{\text {GFRP }}$ is the area of GFRP bars, $A_{s}$ is the area of steel bars, $f_{f u}$ is the ultimate tensile strength of GFRP bar and $\alpha$ is the reduction factor to account for lower compressive strength than tensile strength of GFRP bar. The reduction factor $(\alpha)$ of 0.61 based on the experimental results of tension and compression 
tests of GFRP bars was considered in the analytical modeling of GFRP bars. The axial loads and bending moments of GT, GTGR and REF groups under $25 \mathrm{~mm}$ and $50 \mathrm{~mm}$ eccentric axial loads and four-point load were calculated using the layer-by-layer numerical integration method.

\section{Layer-by-layer Numerical Integration Method}

In the layer-by-layer numerical integration method the circular specimen cross-section was assumed to consist of $n$ layers of unit height (Fig. 3a). It was assumed that plane sections remain plane after bending, tensile strength of concrete is negligible, strain distribution within the circular cross-section of specimen is linear and full composite action between GFRP tube and confined concrete is developed.

In GT and GTGR groups, axial strain $\left(\varepsilon_{c}\right)$ at mid-height of each layer was calculated in terms of ultimate FRP confined concrete strain $\left(\varepsilon_{c u}\right)$ (Equation 26):

$$
\varepsilon_{c}=\varepsilon_{c u} \frac{d_{N}-\left(n * 1-\frac{1}{2}\right)}{d_{N}}
$$

where $d_{N}$ is depth of neutral axis. In REF group, axial strain $\left(\varepsilon_{c}\right)$ at mid-height of each layer was also calculated using Equation (26) by substituting ultimate FRP confined concrete strain $\left(\varepsilon_{c u}\right)$ with concrete crushing strain of 0.003 . In GT and GTGR groups, the axial stress $\left(f_{c}\right)$ at mid-height of each layer corresponding to axial strain $\left(\varepsilon_{c}\right)$ was calculated with Samaan et al. (1998) and Lam and Teng (2003) stress-strain models for FRP confined concrete for comparison purposes. In REF group, the axial stress $\left(f_{c}\right)$ at mid-height of each layer corresponding to axial strain $\left(\varepsilon_{c}\right)$ was calculated with axial stress-axial strain curve of concrete proposed by Popovics (1973). In GT and GTGR groups, the forces in concrete $\left(F_{c i}\right)$ 
417 (28), respectively.

$$
\begin{gathered}
F_{c i}=f_{c} A_{i} \\
F_{t i}=E_{F R P} \varepsilon_{c}\left(A_{o}-A_{i}\right)
\end{gathered}
$$

418 where $A_{o}$ is the outer area of GFRP-CFFT, $A_{i}$ is the area of a layer. In REF group, only $F_{c i}$ 419 (Equation 27) at mid-height of each layer was calculated. In GT, GTGR and REF groups, the 420 moment $\left(M_{i}\right)$ at mid-height of each layer was calculated using Equation (29).

$$
M_{i}=\left(F_{c i}+F_{T i}\right) *\left(\frac{D_{o}}{2}-\left(n * 1-\frac{1}{2}\right)\right)
$$

421 The longitudinal bars in GTGR and REF groups were placed at a distance $\left(d_{i}\right)$ from the 422 extreme compressive fiber in four layers (i.e. $d_{1}, d_{2}, d_{3}$ and $\left.d_{4}\right)$ (Fig. 3b). The strain $\left(\varepsilon_{G i}\right)$ in each GFRP bar layer was calculated using Equation (30) and strain in each steel bar $\left(\varepsilon_{s i}\right)$ layer was calculated using Equation (31).

$$
\begin{gathered}
\varepsilon_{G i}=\varepsilon_{c u} \frac{d_{N}-d_{i}}{d_{N}} \\
\varepsilon_{s i}=0.003 \frac{d_{N}-d_{i}}{d_{N}}
\end{gathered}
$$

425 The stress $\left(f_{G i}\right)$ in each GFRP bar was calculated using Equation (32) and the stress $\left(f_{s i}\right)$ in 426 each steel bar was calculated using Equation (33).

$$
\begin{gathered}
f_{G i}=E_{G i} \varepsilon_{G i} \leq f_{f u} \\
f_{s i}=E_{s} \varepsilon_{s i} \leq f_{y}
\end{gathered}
$$

427 The force $\left(F_{G i}\right)$ in each GFRP bar was calculated using Equation (34) and the force $\left(F_{s i}\right)$ in each steel bar was calculated using Equation (35). 


$$
\begin{gathered}
F_{G i}=f_{G i} A_{G F R P} \\
F_{s i}=f_{s i} A_{s}
\end{gathered}
$$

429

430

431

432 (37).

$$
\begin{gathered}
M_{G F R P}=\sum F_{G i}\left(\frac{D_{o}}{2}-d_{i}\right) \\
M_{\text {STEEL }}=\sum F_{s i}\left(\frac{D_{o}}{2}-d_{i}\right)
\end{gathered}
$$

433

434

435

436

437

The moment produced by GFRP bars $\left(M_{\text {GFRP }}\right.$ ) about the centroid of the circular GFRP-CFFT cross-section was calculated using Equation (36). The moment produced by steel bars $\left(M_{\text {STEEL }}\right)$ about the centroid of the circular REF cross-section was calculated using Equation

\section{Comparison of Analytical and Experimental Axial Load Bending Moment}

\section{Interactions}

The analytical axial load bending moment interactions are compared with the experimental axial load bending moment interactions to validate the developed analytical model. The GT and GTGR groups were designed as alternatives of steel RC (REF group) for the regions where corrosion of steel is a major concern. The analytical axial load bending moment $(P-M)$ interactions of GT and GTGR groups are presented in Fig. 4. For GT group, analytical $P-M$ interaction constructed with Samaan et al. (1998) model matched well with the corresponding experimental $P-M$ interaction at concentric and eccentric axial loads and four-point load (Fig. 4a). For Specimens GT-0, GT-25 and GT-50, analytical axial loads calculated with Samaan et al. (1998) model were 89.3\%, 91.5\% and $81.3 \%$, respectively, of the experimental axial loads. For Specimens GT-25, GT-50 and GT-B, analytical bending moments calculated with Samaan et al. (1998) model were 103.4\%, 96.9\% and $115.9 \%$, respectively, of the experimental bending moments. For GT group, analytical $P-M$ interaction constructed with Lam and Teng (2003) model underestimated the axial 
loads and bending moments of the corresponding experimental $P-M$ interaction (Fig. 4a). For Specimens GT-0, GT-25 and GT-50, analytical axial loads calculated with Lam and Teng (1998) model were $89.1 \%, 92.8 \%$ and $83.5 \%$, respectively, of the experimental axial loads. For Specimens GT-25, GT-50 and GT-B, analytical bending moments calculated with Lam and Teng (1998) model were 95\%, 92.4\% and 97.2\%, respectively, of the experimental bending moments. In general for GT group, analytical axial loads and bending moments calculated with Samaan et al. (1998) and Lam and Teng (2003) models resulted in conservative estimates. This conservative estimate was because analytical axial loads and bending moments were calculated based on ultimate GFRP confined concrete strain in compression with Samaan et al. (1998) and Lam and Teng (1998) models. Moreover in eccentrically loaded FRP confined concrete specimens, the actual confined concrete strain may exceed the analytically computed FRP confined concrete strain in the compression regions.

For GTGR groups, analytical $P-M$ interaction constructed with Samaan et al. (1998) model matched very well with the corresponding experimental $P-M$ interaction at concentric and eccentric axial loads and four-point load (Fig. 4b). For Specimens GTGR-0, GTGR-25 and GTGR-50, analytical axial loads calculated using Samaan et al. (1998) model were $93.5 \%, 102.5 \%$ and $116.7 \%$, respectively, of the experimental axial loads. For Specimens GTGR-25, GTGR-50 and GTGR-B, analytical bending moments calculated with Samaan et al. (1998) model were $88.2 \%, 98.8 \%$ and $92.1 \%$, respectively, of the experimental bending moments. For GTGR group, analytical $P-M$ interaction constructed with Lam and Teng (2003) model underestimated the axial loads and bending moments of the 470 corresponding experimental $P-M$ interaction. For Specimens GTGR-0, GTGR-25 and GTGR-50, analytical axial loads calculated with Lam and Teng (1998) model were 93.3\%, 
473 GTGR-50 and GTGR-B, analytical bending moments calculated with Lam and Teng (1998)

474 model were $69.8 \%, 82.4 \%$ and $88 \%$, respectively, of the experimental bending moments. For

475 GTGR group, analytical axial loads and bending moments calculated with Lam and Teng

476 (2003) model were more conservative than those calculated with Samaan et al. (1998) model.

477 This was because ultimate GFRP confined concrete strain computed with Lam and Teng 478 (2003) model was smaller than ultimate GFRP confined concrete strain computed with 479 Samaan et al. (1998) model. The smaller ultimate strains in GFRP confined concrete resulted in smaller strains in GFRP bars because of an assumption of strain compatibility between GFRP bar and GFRP tube confined concrete. The smaller strains in GFRP bars resulted in smaller stresses and corresponding smaller forces and bending moments in GFRP bars. Hence, analytical axial loads and bending moments of GTGR group predicted with Lam and Teng (2003) model were more conservative than those calculated with Samaan et al. (1998) model.

For REF group, analytical $P-M$ interaction constructed with axial stress-axial strain curve of concrete proposed by Popovics (1973) matched very well with the corresponding experimental $P-M$ curve at concentric and eccentric axial loads and four-point load (Fig. 5). For Specimens REF-0, REF-25 and REF-50, analytical axial loads were 93\%, 97\% and 93\%, respectively, of the experimental axial loads. Similarly, for Specimens REF-25, REF-50 and REF-B, analytical bending moments were $90 \%, 90 \%$ and $92 \%$, respectively, of the experimental bending moments. The analytical results showed that REF specimen can be accurately modeled as unconfined concrete specimen and this approach is consistent with the approach adopted by ACI 318M-2011 (ACI 2011) for design purposes. Also, the layer-bylayer numerical integration method adopted in this study can be used to accurately predict the axial loads and bending moments of GT, GTGR and REF groups. 


\section{Parametric Study}

499 A parametric study was conducted to study the effects of actual confinement ratio and GFRP bar reinforcement ratio on axial loads and bending moments of GFRP-CFFT reinforced with GFRP bars (GTGR group) tested under concentric and eccentric axial loads and four-point load. The parametric study considered GFRP-CFFT (206 mm outer diameter and $812 \mathrm{~mm}$ height) reinforced with six GFRP bars (15.9 mm nominal diameter i.e., $\rho=2.35 \%)$. The GTGR group with four actual confinement ratios (i.e., 0.1, 0.2, 0.3 and 0.4) and GFRP bar reinforcement ratio ( $\rho=3.67 \%$ ) were considered to study the effect of actual confinement ratio $\left(f_{l, a} / f_{c o}\right)$ on $P-M$ interactions. The $f_{l, a} / f_{c o}$ values chosen in this parametric study were greater than the limiting actual confinement ratio $\left(f_{l, a} / f_{c o} \geq 0.073\right)$ required to ensure a non-descending second branch in the axial stress-strain performance (ACI 2008). The GTGR group reinforced with GFRP bars of four different nominal diameters $(9.5 \mathrm{~mm}, 12.7 \mathrm{~mm}$, $15.9 \mathrm{~mm}$ and $19.1 \mathrm{~mm}$ ) resulted in four different GFRP bar reinforcement ratios (i.e. $1.32 \%$, $2.35 \%, 3.67 \%$ and $5.29 \%)$ and actual confinement ratio $\left(f_{l, a} / f_{c o}=0.2\right)$ were also considered to study the effect of increasing GFRP bar reinforcement ratio on $P-M$ interactions. Samaan et al. (1998) stress-strain model for FRP confined concrete was used to analytically model GFRP-CFFT and the layer-by-layer numerical integration method was used to analyze circular specimen cross-section. The $P-M$ interactions were constructed using normalized axial loads $\left(P^{*}\right)$ (Equation 38) and normalized bending moments $\left(M^{*}\right)$

517 (Equation 39).

$$
\begin{gathered}
P^{*}=\frac{P}{f_{c o} A_{g}} \\
M^{*}=\frac{M}{f_{c o} A_{g} D}
\end{gathered}
$$


518 Fig. 6(a) demonstrated the increased normalized axial loads and bending moments of GTGR 519 group with increase in actual confinement ratios from 0.1 to 0.4. Fig. 6(a) also demonstrated that increasing actual confinement ratio resulted in larger increase in axial loads under concentric and eccentric axial loads than in flexural loads and corresponding bending

522 moments under four-point load. This was because two-thirds of the fibers in GFRP tube were oriented along the circumferential direction which were effective in confining the dilated concrete core and hence increased the axial loads. However, fibers oriented in circumferential direction were less effective under four-point load and only one-third of fibers oriented perpendicular to circumferential direction, which were effective under four-point load.

Fig. 6(b) demonstrated that increasing GFRP bar reinforcement ratio resulted in increase in normalized axial loads and bending moments (enlarged $P-M$ curves) of GTGR group. Figure 6(b) also demonstrated that increasing GFRP bar reinforcement ratio resulted in slightly larger increase in flexural loads and corresponding bending moments than peak axial loads. This was because GFRP bars under four-point load were effective in resisting load and, also, GFRP bars have higher ultimate strength in tension than in compression.

\section{Conclusions}

534 This study investigated experimentally and analytically the axial-flexural $(P-M)$ interactions of steel RC (REF), GFRP-CFFT (GT) and GFRP bar reinforced GFRP-CFFT (GTGR) groups. A parametric study was also conducted to determine the effects of actual confinement ratio and GFRP bar reinforcement ratio on axial-flexural interactions. The following conclusions are drawn based on the experimental and analytical results: GT and REF group as GTGR group resisted higher axial and flexural loads, and lateral 
541 deformations at peak axial loads than GT and REF groups. The confinement effectiveness of

542 GFRP tube was reduced with the increase in applied axial load eccentricity.

543 For GT and GTGR groups, analytical axial loads and bending moments calculated using 544 Samaan et al. (1998) and Lam and Teng (2003) stress-strain models underestimated the 545 experimental axial loads and bending moments resulting in conservative estimates. Also, the 546 layer-by-layer numerical integration method adopted here can be used to accurately compute 547 the axial loads and bending moments of GT, GTGR and REF groups.

548 The parametric study results showed that increase in confinement ratio resulted in larger 549 increase in peak axial loads than flexural loads and corresponding bending moments of 550 GTGR group. Increase in GFRP bar reinforcement ratio resulted in slightly larger increase in 551 flexural load and corresponding bending moments than peak axial loads of GTGR group.

552 Based on the experimental and analytical results presented in this study, GTGR group can 553 serve as an alternative of REF group under concentric and eccentric axial loads and flexural 554 load in structural applications for which corrosion of steel bar is a concern. However, GT 555 group can serve as an alternative of REF group only under concentric axial load.

\section{Acknowledgements}

557 The authors thank the University of Wollongong, Australia for providing the funding and 558 facilities to carry out the experimental work. The authors also acknowledge the technical 559 assistance provided by Technical Officer Mr. Fernando Escribano. The first author thanks the 560 University of Engineering and Technology, Lahore and Higher Education Commission (HEC) of Pakistan and the University of Wollongong, Australia for funding his $\mathrm{PhD}$ studies. 


\section{References}

ACI (American Concrete Institute) (2006). "Guide for the Design and Construction of Structural Concrete Reinforced with FRP Bars." ACI 440.1R-06, Farmington Hills, MI 48331, USA.

ACI (American Concrete Institute) (2008). Guide for the Design and Construction of Externally Bonded FRP Systems for Strengthening Concrete Structures. ACI 440.2R2008. United States.

ACI (American Concrete Institute). (2011). "Building Code Requirements for Structural Concrete and Commentary." ACI 318M-11, Farmington Hills, MI 48331, USA.

ACI (American Concrete Institute). (2015). "Guide for the Design and Construction of Structural Concrete Reinforced with FRP Bars." ACI 440.1R-15, Farmington Hills, MI 48331, USA.

Afifi, M., Mohamed, H. \& Benmokrane, B. (2014a). "Axial capacity of circular concrete columns reinforced with GFRP bars and spirals." Journal of Composites for Construction, 04013017.

Afifi, M., Mohamed, H. \& Benmokrane, B. (2014b). "Strength and axial behavior of circular concrete columns reinforced with CFRP Bars and Spirals." Journal of Composites for Construction, 04013035.

Alsayed, S., Al-Salloum, Y., Almussallam, T., El-Gamal, S. \& Aqel, M. (2012). "Performance of glass fiber reinforced polymer bars under elevated temperatures." Composites Part B: Engineering, 43, 2265-2271.

AS (Australian Standard). (1999). "Methods of testing concrete, Method 9: Determination of the compressive strength of concrete specimens. AS 1012.9-1999. Sydney, NSW: Standards Australia.

AS (Australian Standard). (2007). "Metallic materials-Tensile testing at ambient temperature." AS1391-2007, Sydney, NSW.

ASTM (American Society for Testing and Materials). (2010). "Standard Test Method for Compressive Properties of Rigid Plastics." D695-10, 100 Barr Harbor Drive, PO Box C700, West Conshohocken, PA 19428-2959, USA.

ASTM (American Society for Testing and Materials). (2011). "Standard Test Method for Tensile Properties of Fiber Reinforced Polymer Matrix Composite Bars." D7205/D7205M-11, 100 Barr Harbor Drive, PO Box C700, West Conshohocken, PA 19428-2959, USA.

CSA (Canadian Standards Association). (2012). "Design and construction of building components with fiber reinforced polymers." CSA S806-12. Toronto.

CST Composites 2014, accessed 30 March 2014, < http://www.cstcomposites.com/productsand-services/tubes-rods-and-components $>$

De Lorenzis, L. \& Tepfers, R. (2003). "Comparative study of models on confinement of concrete cylinders with Fiber-Reinforced Polymer composites. Journal of Composites for Construction, 7, 219-237.

De Luca, A., Matta, F. \& Nanni, A. (2010). "Behavior of full scale glass Fiber Reinforced Polymer reinforced concrete columns under axial load." ACI Structural Journal, 107, 589-596.

Deitz, D., Harik, I. \& Gesund, H. (2003). "Physical properties of glass Fiber Reinforced Polymer rebars in compression." Journal of Composites for Construction, 7, 363-366. 
Fam, A. \& Rizkalla, S. (2001). "Concrete filled FRP tubes for flexural and axial compression members." ACMBS-MCAPC.

Fam, A. \& Rizkalla, S. (2002). "Flexural behavior of Concrete-Filled Fiber-Reinforced Polymer circular tubes. Journal of Composites for Construction, 6, 123-132.

Fam, A., Flisak, B. \& Rizkalla, S. (2003). "Experimental and analytical modelling of concrete filled fiber reinforced polymer tubes subjected to combined bending and axial loads." ACI Structural Journal, 100(4), 499-509.

Fam, A., Schnerch, D. \& Rizkalla, S. (2005). "Rectangular Filament-Wound Glass Fiber Reinforced Polymer Tubes Filled with Concrete under Flexural and Axial Loading: Experimental Investigation. Journal of Composites for Construction, 9, 25-33.

Fanggi, B. A. L., and Ozbakkaloglu, T. (2015). "Behavior of hollow and concrete-filled FRPHSC and FRP-HSC-steel composite columns subjected to concentric compression." Advances in Structural Engineering, 18(5), 715-738.

Gu, D., Wu, G., Wu, Z. \& Wu, Y. (2010). "Confinement effectiveness of FRP in retrofitting circular concrete columns under simulated seismic load." Journal of Composites for Construction, 14, 531-540.

Hadi, M. N. S., Khan, Q. S. \& Sheikh, M. N. (2016a). "Axial and flexural behavior of unreinforced and FRP bar reinforced circular concrete filled FRP tube columns." Construction and Building Materials, 122, 43-53.

Hadi, M. N. S., Karim H., \& Sheikh M.N. (2016b). "Experimental investigations on circular concrete columns reinforced with GFRP bars and helices under different loading conditions". Journal of Composites for Construction;. (DOI: Permalink: http://dx.doi.org/10.1061/(ASCE)CC.1943-5614.0000670)

Hadi, M. N. S., Pham, T. \& Lei, X. (2013). "New method of strengthening reinforced concrete square columns by circularizing and wrapping with Fiber-Reinforced Polymer or steel straps. Journal of Composites for Construction, 17, 229-238.

Hong, W. K. \& Kim, H. C. (2004). "Behavior of concrete columns confined by carbon composites tubes." Canadian Journal of Civil Engineering, 31(2), 178-188.

Idris, Y., \& Ozbakkaloglu, T. (2014). "Flexural behavior of FRP-HSC steel composite beams." Thin-Walled Structures, 80, 207-216.

Idris, Y., \& Ozbakkaloglu, T. (2015). "Flexural behavior of FRP-HSC-steel double skin tubular beams under reversed-cyclic loading." Thin-Walled Structures, 87, 89-101.

ISO (International Standard). (2015). "Fibre-reinforced polymer (FRP) reinforcement of concrete - Test methods - Part 1: FRP bars and grids" ISO 10406-1:2015, Switzerland.

Khan, Q. S., Sheikh, M. N. \& Hadi, M. N. S. (2016). "Axial compressive behavior of circular CFFT: Experimental database and design oriented model." Steel and Composite Structures, 21(4), 921-947.

Kobayashi, K. \& Fujisaki, T. (1995). "Compressive behavior of FRP reinforcement in nonprestressed concrete members." In Proc., The Second International RILEM 
Symposium of Nonmetallic (FRP) reinforcement for concrete structures (FRPRCS-2), London, England.

Lam, L. \& Teng, J. G. (2003). "Design-oriented stress-strain model for FRP-confined concrete." Construction and Building Materials, 17, 471-489.

Lillistone, D. \& Jolly, C. K. (2000). "An innovative form of reinforcement for concrete columns using advanced composites." The Structural Engineer, 78, 20-29.

Mirmiran, A., Samaan, M., Cabrera, S. \& Shahawy, M. (1998a). "Design, manufacture and testing of a new hybrid column." Construction and Building Materials, 12, 39-49.

Mirmiran, A., Shahawy, M. \& Samaan, M. (1998b). "Strength and ductility of hybrid FRPConcrete beam-columns." Journal of Structural Engineering, 125, 1085-1093.

Mohamed, H. \& Masmoudi, R. (2008a). "Behavior of the concrete filled FRP tube columns under eccentric load." Structural composites for Infrastructure Applications (MESC5). Hurghada, Egypt.

Mohamed, H. \& Masmoudi, R. (2008b). "Compressive behavior of reinforced concrete filled FRP tubes." ACI-SP, SP-257, 91-108.

Mohamed, H. M. \& Masmoudi, R. (2010). "Flexural strength and behavior of steel and FRPreinforced concrete-filled FRP tube beams." Engineering Structures, 32, 3789-3800.

Mohamed, M. H., Afifi, M. Z. \& Benmokrane, B. (2014). "Performance evaluation of concrete columns reinforced longitudinally with FRP Bars and confined with FRP hoops and spirals under axial load." Journal of Bridge Engineering, 19, 04014020.

Ozbakkaloglu, T. \& Saatcioglu, M. (2006). "Seismic behavior of high-strength concrete columns confined by Fiber-Reinforced Polymer tubes." Journal of Composites for Construction, 10, 538-549.

Ozbakkaloglu, T. (2013). "Compressive behavior of concrete-filled FRP tube columns: Assessment of critical column parameters." Engineering Structures, 51, 188-199.

Pantelides, C., Gibbons, M. \& Reaveley, L. (2013). "Axial load behavior of concrete columns confined with GFRP spirals." Journal of Composites for Construction, 17, 305-313.

Popovics, S. (1973). "A numerical approach to the complete stress strain curves for concrete." Cement and Concrete Research, 3, 583-599.

Samaan, M., Mirmiran, A. \& Shahawy, M. (1998). Model of Concrete Confined by Fiber Composites. Journal of Structural Engineering, 124, 1025-1031.

Tasdemir, M. A., Tasdemir, C., Akyüz, S., Jefferson, A. D., Lydon, F. D. \& Barr, B. I. G. (1998). "Evaluation of strains at peak stresses in concrete: A three-phase composite model approach." Cement and Concrete Composites, 20, 301-318.

Tobbi, H., Farghaly, A. S. \& Benmokrane, B. (2012). "Concrete columns reinforced longitudinally and transversally with glass Fiber-Reinforced Polymer bars." ACI Structural Journal, 109, 551-558.

Vincent, T. \& Ozbakkaloglu, T. (2013). "Influence of fiber orientation and specimen end condition on axial compressive behavior of FRP confined concrete." Construction and Building Materials, 47, 814-826.

V-Rod (2012). "Composite reinforcing rods technical data sheet." Largs Bay SA, Australia.

Wang, W., Sheikh, M. N. \& Hadi, M. N. S. (2016). "Experimental study on FRP tube reinforced concrete columns under different loading conditions." Journal of 
704

705

706

707

708

709

710

711

712

713

714

715

716

717

718

719

Composites for Construction, http://dx.doi.org/10.1061/(ASCE)CC.19435614.0000690 .

Xiao, Y., Wu, H. \& Martin, G. R. (1999). "Prefabricated composite jacketing of RC columns for enhanced shear strength." Journal of Structural Engineering, 125, 255-264.

Yamakawa, T., Zhong, P. \& Ohama, A. (2003). "Seismic performance of aramid fiber square tubed concrete columns with metallic and/or non-metallic reinforcement." Journal of Reinforced Plastics and Composites, 22, 1221-1238.

Zadeh, H. \& Nanni, A. (2013). Design of RC columns using Glass FRP reinforcement." Journal of Composites for Construction, 17, 294-304.

Zhu, Z., Ahmad, I. \& Mirmiran, A. (2006). "Seismic performance of concrete-Filled FRP tube columns for bridge substructure." Journal of Bridge Engineering, 11, 359-370.

\section{(1)}


Table 1. Experimental Program

722 Table 2. Test results of column specimens

723 Table 3. Test results of beam specimens

724

725

726

727

728

729

730

731

732

733

734

735

736

737

738

739

740

741

742 
744 Fig. 1. Experimental axial load bending moment interactions of REF, GT and GTGR groups

745 Fig. 2. Confinement mechanism of FRP confined concrete

746 Fig. 3. Stress and strain profiles for computing P-M interactions of groups: (a) GT, and (b)

747 GTGR and REF

748 Fig. 4. Experimental and analytical axial load bending moment interactions of groups: (a)

749 GT, and (b) GTGR

750 Fig. 5. Experimental and analytical axial load bending moment interactions of REF group

751 Fig. 6. Normalized $P^{*}-M^{*}$ interactions of GTGR group for different (a) actual

752 confinement ratios, and (b) reinforcement ratios

753

754

755

756

757

758

759 
Table 1. Experimental Program

\begin{tabular}{cccccc}
\hline Specimen ID & $\begin{array}{c}\text { Outer } \\
\text { diameter } \\
(\mathrm{mm})\end{array}$ & Height $(\mathrm{mm})$ & $\begin{array}{c}\text { Lateral } \\
\text { confinement }\end{array}$ & $\begin{array}{c}\text { Longitudinal } \\
\text { bars }\end{array}$ & $\begin{array}{c}\text { Test } \\
\text { Eccentricity }\end{array}$ \\
\hline REF-0 & 205 & 800 & Steel helix & Steel & 0 \\
REF-25 & 205 & 800 & Steel helix & Steel & 25 \\
REF-50 & 205 & 800 & Steel helix & Steel & 50 \\
REF-B & 205 & 800 & Steel helix & Steel & Four-point load \\
GT-0 & 206 & 812 & GFRP tube & - & 0 \\
GT-25 & 206 & 812 & GFRP tube & - & 25 \\
GT-50 & 206 & 812 & GFRP tube & - & 50 \\
GT-B & 206 & 812 & GFRP tube & - & Four-point load \\
GTGR-0 & 206 & 812 & GFRP tube & GFRP & 0 \\
GTGR-25 & 206 & 812 & GFRP tube & GFRP & 25 \\
GTGR-50 & 206 & 812 & GFRP tube & GFRP & 50 \\
GTGR-B & 206 & 812 & GFRP tube & GFRP & Four-point load \\
\hline
\end{tabular}




\begin{tabular}{ccccccc}
$\begin{array}{c}\text { Specimen } \\
\text { ID }\end{array}$ & $\begin{array}{c}\text { Peak } \\
\text { axial } \\
\text { load } \\
(\mathrm{kN})\end{array}$ & $\begin{array}{c}\text { Axial } \\
\text { deformation } \\
\text { at peak } \\
\text { axial load } \\
(\mathrm{mm})\end{array}$ & $\begin{array}{c}\text { Lateral } \\
\text { deformation } \\
\text { at peak } \\
\text { axial load } \\
\delta(\mathrm{mm})\end{array}$ & $\begin{array}{c}\text { Bending } \\
\text { moment } \\
M \\
(\mathrm{kN} . \mathrm{m})\end{array}$ & $\begin{array}{c}\text { Mid-height } \\
\text { circumferential } \\
\text { strain on tension } \\
\text { side at Peak } \\
\text { axial load }\end{array}$ & $\begin{array}{c}\text { Strain in } \\
\text { bars at } \\
\text { mid-height } \\
\text { at peak } \\
\text { axial load }\end{array}$ \\
\hline REF-0 & 1529 & 2.4 & - & - & 0.0010 & 0.0156 \\
REF-25 & 888 & 4.2 & 3.3 & 25.1 & 0.0005 & 0.0112 \\
REF-50 & 594 & 3.2 & 3.2 & 31.6 & 0.0001 & 0.0075 \\
GT-0 & 1884 & 21.3 & - & - & 0.0126 & - \\
GT-25 & 860 & 4.2 & 5.8 & 26.5 & 0.0030 & - \\
GT-50 & 523 & 4.1 & 4.0 & 28.2 & 0.0005 & - \\
GTGR-0 & 2812 & 23.1 & - & - & 0.0032 & 0.0068 \\
GTGR-25 & 1487 & 13.5 & 13.4 & 57.1 & 0.0077 & 0.0086 \\
GTGR-50 & 910 & 11.6 & 21.0 & 64.6 & 0.0018 & 0.0072 \\
\hline
\end{tabular}




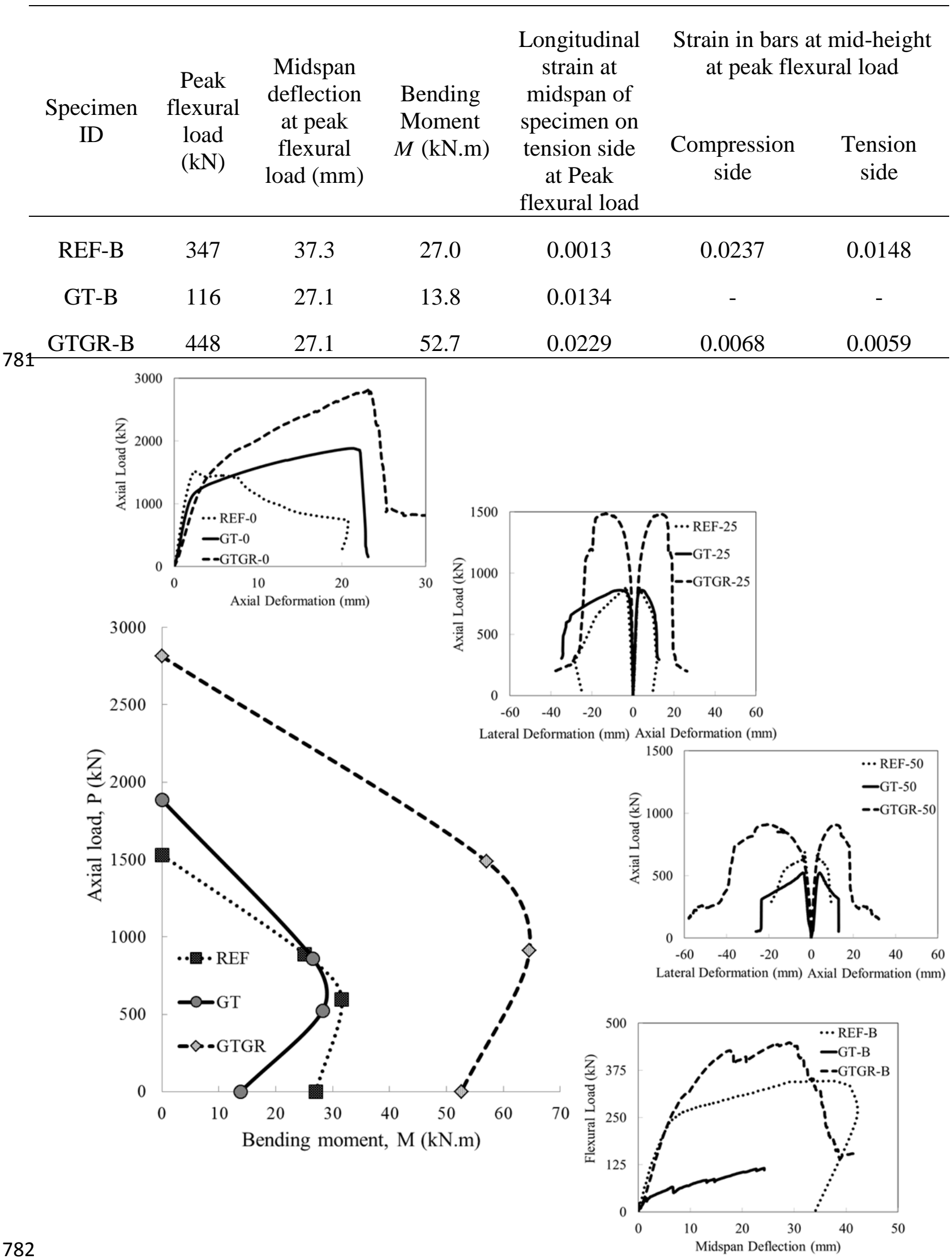


789

791

792

793

794

795

796

799

801

803

804

805

806

807

808

809

810

811

813

815

816

817

818

819

820

821

822

824

825

Fig. 1. Experimental axial load bending moment interactions of REF, GT and GTGR groups

$$
f_{l, a}
$$

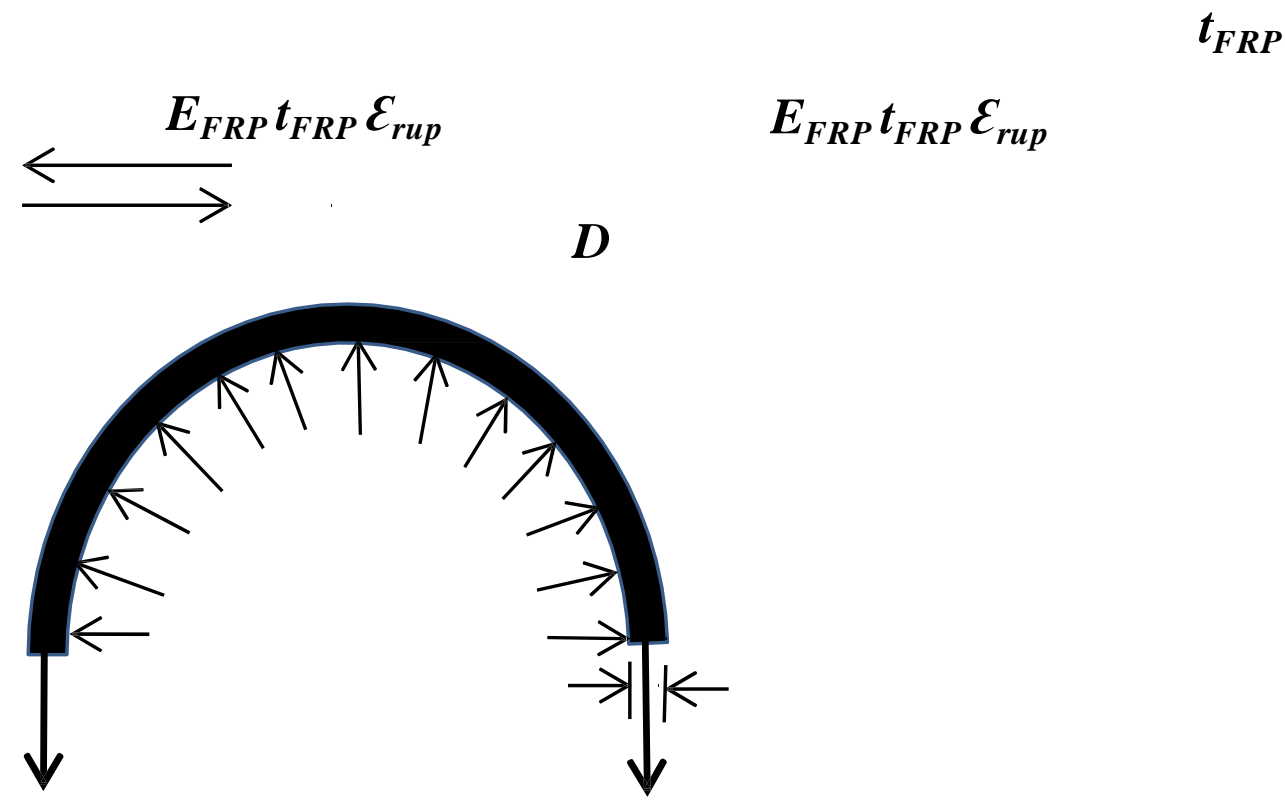

Fig. 2. Confinement mechanism of FRP confined concrete

$$
\begin{aligned}
& 3000 \\
& 2500 \\
& \mathrm{Z} \\
& \text { - Experimental } \\
& \text { •. - Sarnaan et a!. (1998) } \\
& -\diamond \text { Lam and Teng (2003) } \\
& \text { C } 2000 \\
& -\mathrm{O} \\
& \text {..2 } \\
& \text { c. } 1500 \\
& 1000 \\
& 500
\end{aligned}
$$




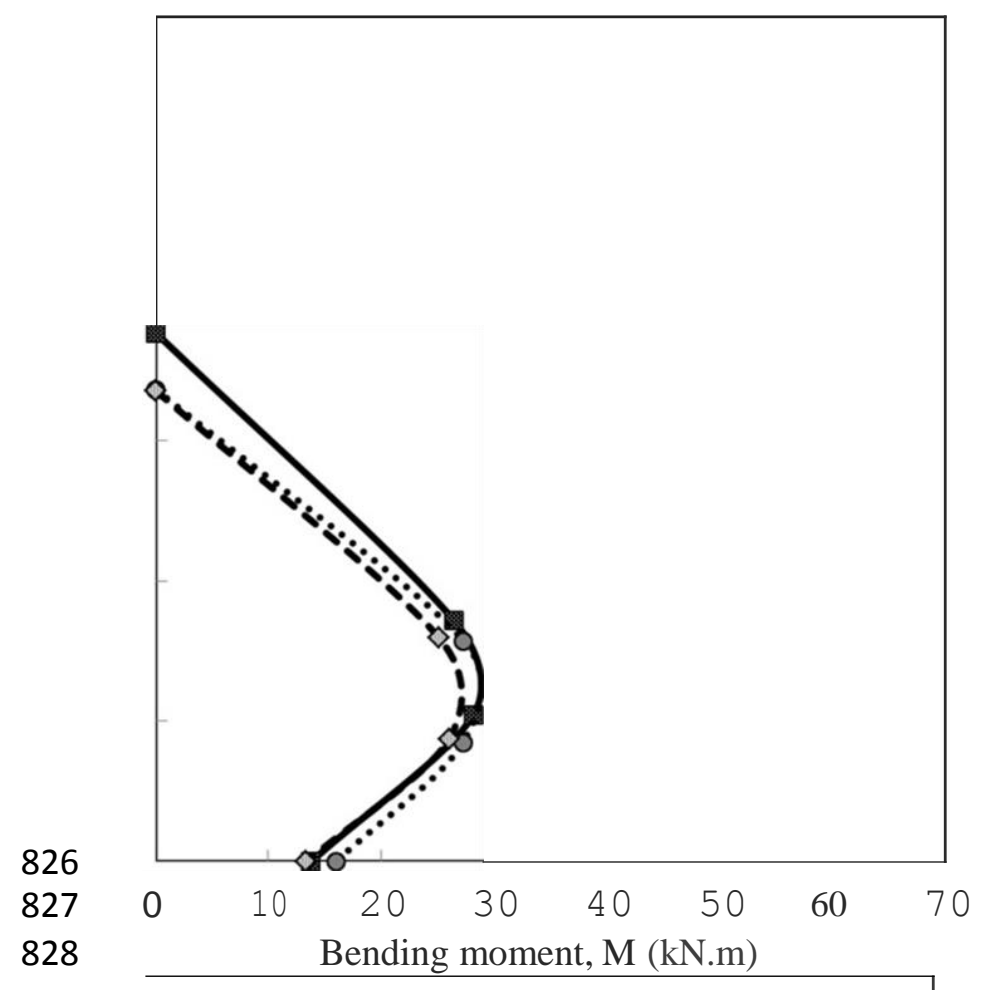

(a) GT 


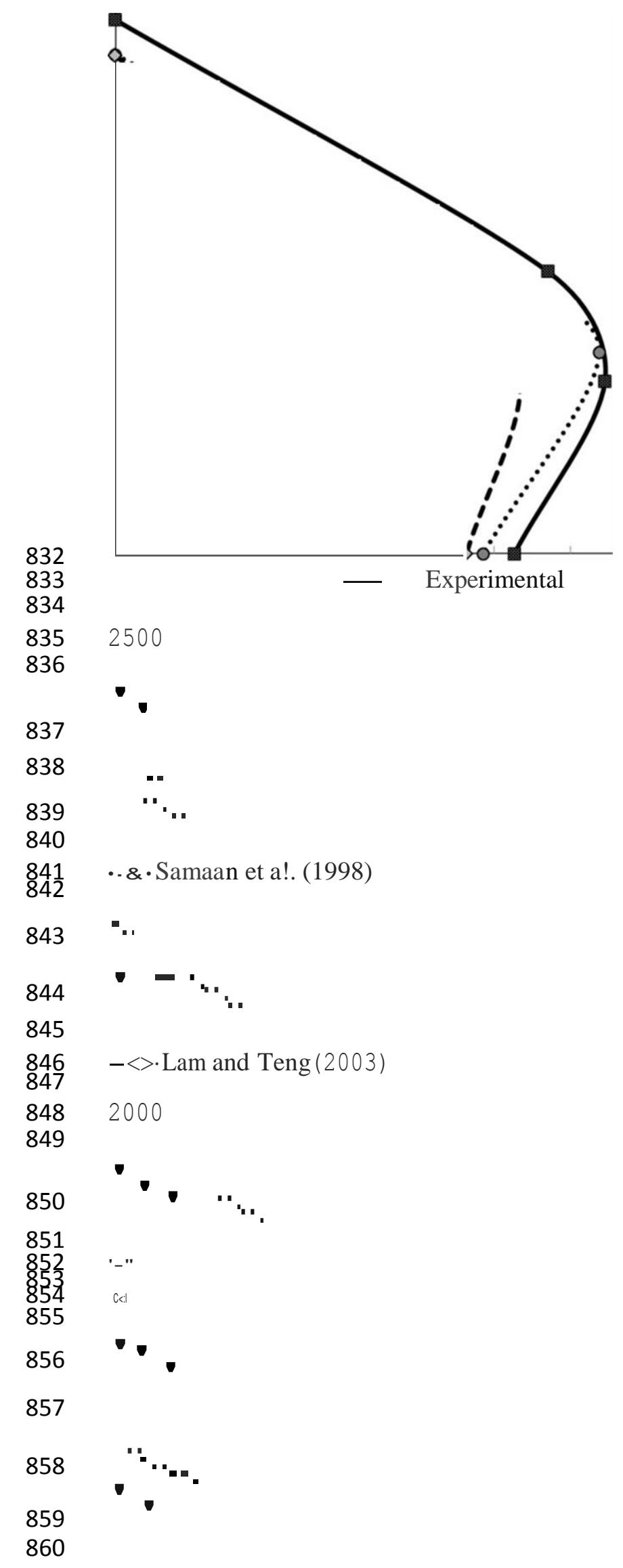


861

862

863

864

865

866

868

869

871

872

873

874

875

876

877

878

879

880

881

882

883

884

885

886

887

888

889

890

891

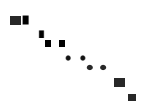

1000

...

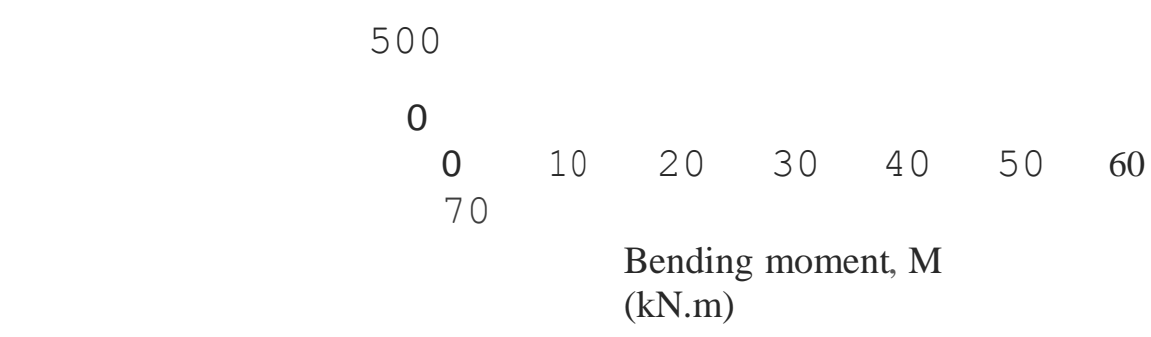

(b)

GTGR

Fig. 4. Experimental and analytical axial load bending moment interactions of groups: (a) GT, and (b) GTGR 


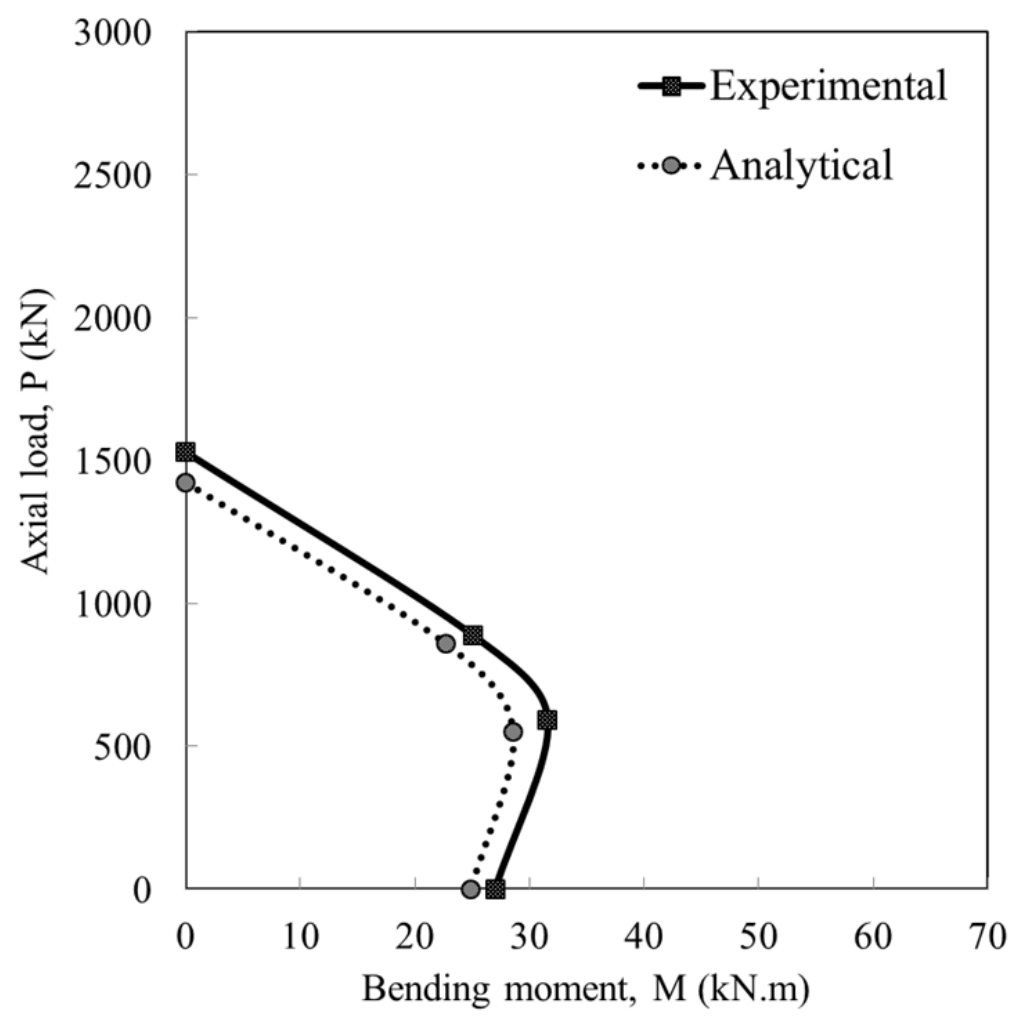

Fig. 5. Experimental and analytical axial load bending moment interactions of REF group

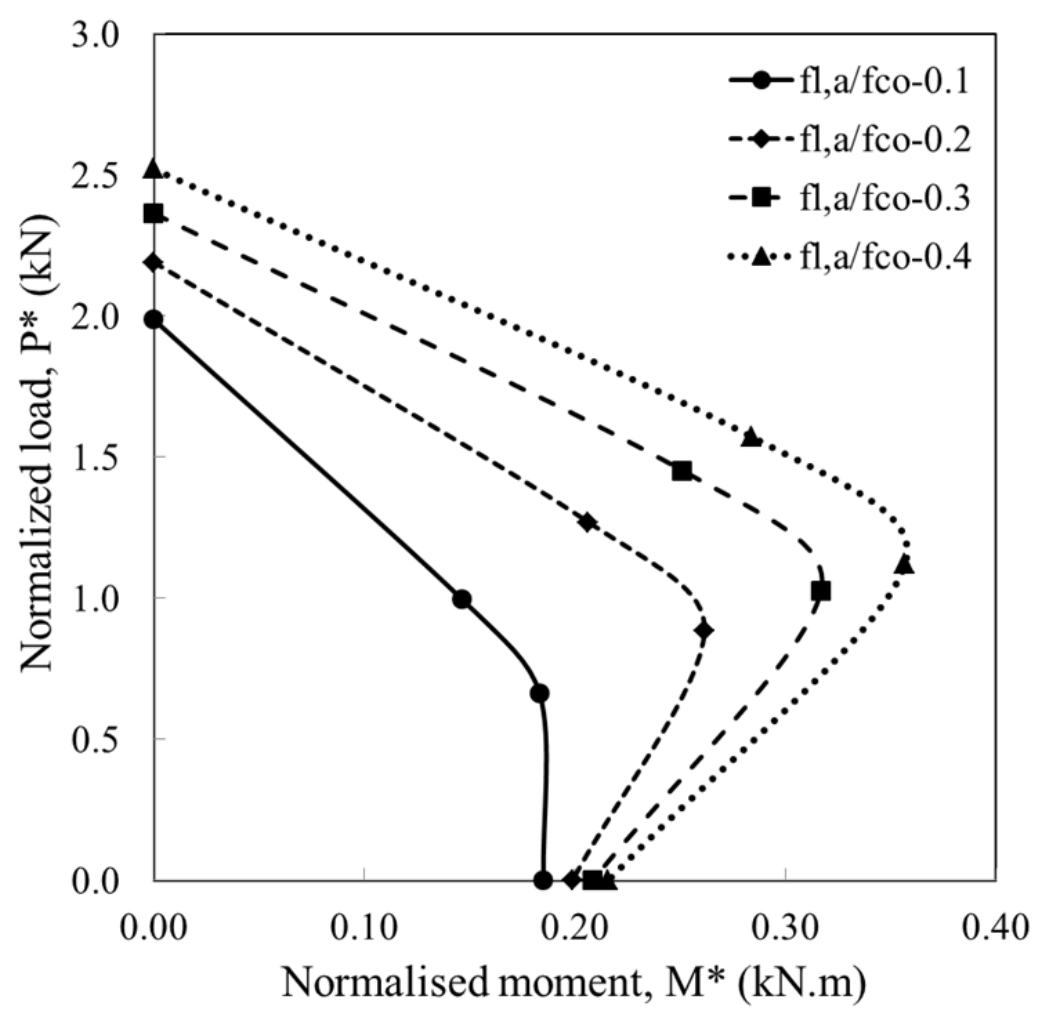




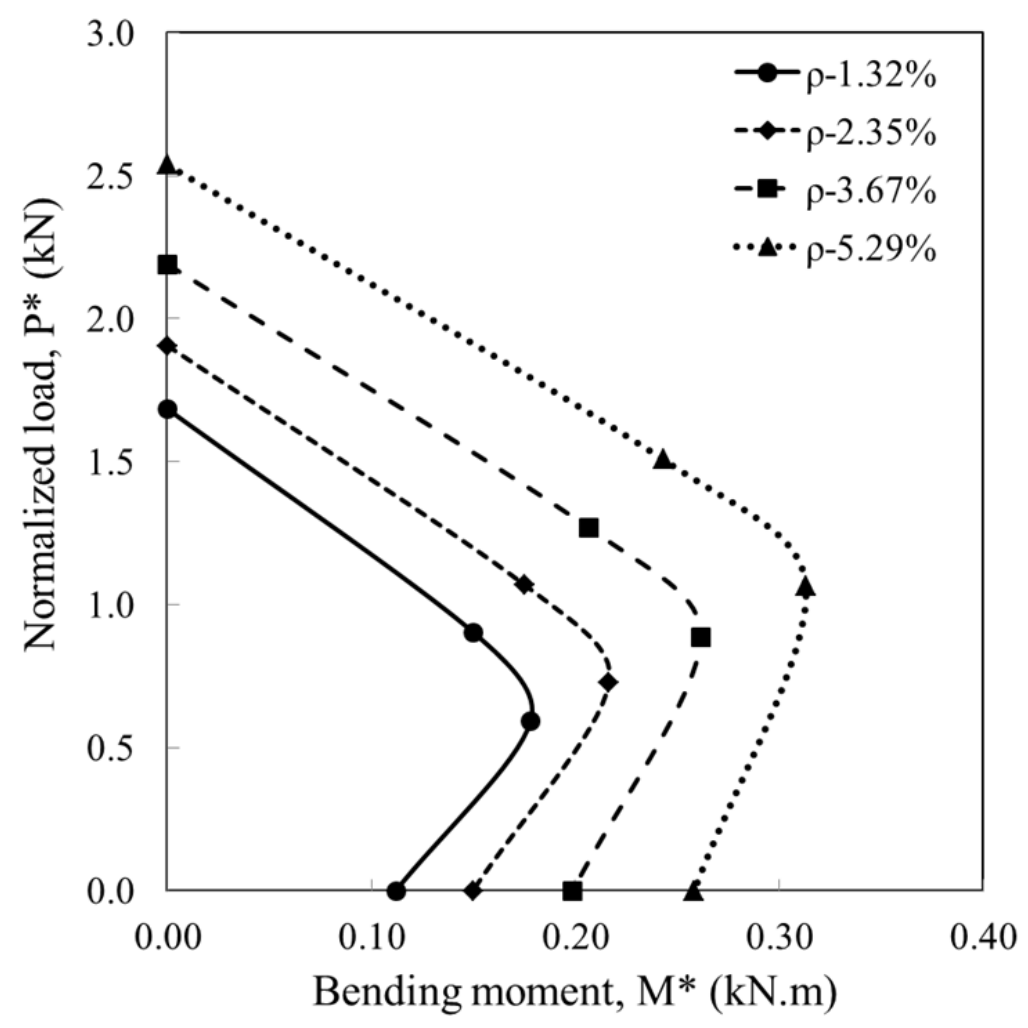

901

903

904

905

907

908

(b)

Fig. 6. Normalized

$P *-M *$ interactions of GTGR group for different (a) actual confinement ratios, and (b) reinforcement ratios

909 